\title{
Laparoscopic Management of Perineal Descent Syndrome in Pediatric Age Group
}

\author{
Ali Ibrahim Ali Ahmed ${ }^{1, *}$ MSc; Magid Mohamed Ismail ${ }^{1}$ MD ; Magdy Mahmoud Mostafa ${ }^{2}$ MD \\ Mohamed Abd Alrazik Dosoky ${ }^{1}$ MD
}

*Corresponding Author:

Ali Ibrahim Ali Ahmed

dr.3li2015@gmail.com

Received for publication Septmber 7 , 2020; Accepted November 20, 2020, Published online November 20, 2020.

Copyright 2020 The Authors published by Al-Azhar University, Faculty of Medicine, Cairo, Egypt. All rights reserved. This an openaccess article distributed under the legal terms, where it is permissible to download and share the work provided it is properly cited. The work cannot be changed in anyway or used commercially.

doi: 10.21608/aimj.2020.41531.1315

${ }^{1}$ Pediatric Surgery Department, Faculty of Medicine, Al-Azhar University, Cairo, Egypt.

${ }^{2}$ General Surgery Department, Faculty of Medicine, Al-Azhar University, Cairo, Egypt.

\begin{abstract}
Background: Perineal descent syndrome is a disease that affects the pelvic floor because of denervation of its muscles, resulting in obstructed defecation. Hints on the anatomy that may be associated with the work got, and the physiology of the anorectum was explained, discussing factors leading to continence and mechanism of defecation was presented.

Aim of work: to diagnose the perineal descent syndrome in both cases of chronic constipation and anal incontinence and usage of laparoscopy to treat PDS in children where the pathophysiological changes are known for each case and dealt with laparoscopically.

Patient and Methods: This research was a forward-looking case study conducted during the period from June 2019 to June 2020 in the department of Pediatric Surgery, Al-Azhar university hospitals after approval by the $\mathrm{Al}$ Azhar Faculty of Medicine Ethical Review Committee. The research included 30 patients presented to the outpatient clinics with constipation or Fecal incontinence whom fulfilled the required Criteria.

Results: In our study ( $\mathrm{n}=30), 2$ recurrent cases $(13.3 \%)$ were found after laparoscopic suture rectopexy. Recurrence rates with mesh rectopexy or resection rectopexy was zero \% and chronic constipation and fecal incontinence are considered as a hidden cause for perineal descent syndrome.

Conclusion: The anterior rectal wall has a great dynamic role in defecation thanks to its viscoelastic properties. Any rectopexy technique should never interfere or impede this vital mechanism of action. Finally chronic constipation and fecal incontinence are considered as a hidden cause for perineal descent syndrome.
\end{abstract}

Keywords: PDS; obstructed defecation; rectocele.

Disclosure: The authors have no financial interest to declare in relation to the content of this article. The Article Processing Charge was paid for by the authors.

Authorship: All authors have a substantial contribution to the article.

\section{INTRODUCTION}

Perineal descent syndrome was identified with respect to various anorectal conditions, including constipation, obstructed defecation, fecal incontinence and rectal or pelvic pain. ${ }^{1}$

Perineal descent syndrome found not only in patients with constipation but also in approximately $75 \%$ of fecal incontinence patients and is widely recognized as a secondary condition associated with multiple diseases causing obstruction of the pelvic outlet rather than an independent disease inducing chronic constipation. Long-term excessive strain for defecation causes the anterior rectal wall protruding into the anal canal; this leads to a feeling of insufficient defecation and weakening of muscles of the pelvic floor resulting in greater and excessive straining and muscle weakness in the pelvic floor leads to a vicious cycle. A sigmoidocele, anal dyschezia, rectocele, non-relaxing puborectalis syndrome rectal intussusception, is generally known as illnesses associated with obstructed defecation, according to the findings of the same study. We then investigated the relationship between the perineal descent level and the pelvic outlet obstruction and the impact of perineal descent on its management. Relevant objectives of laparoscopic management of perineal descent syndrome are to eradicate the problem, enhance continence, enhance intestinal function, and reduce recurrence . ${ }^{2}$

The growing body of literature supports the notion that laparoscopic surgical techniques for repair of perineal descent syndrome offer the benefits safely early return of bowel function, short hospital stay, Improved functional outcome, low recurrence rates and less postoperative pain. 


\section{PATIENT AND MATERIALS}

Study design: This research was a forward-looking case study which was carried out in pediatric surgery department, Al-Azhar university hospitals for the period June 2019 to June 2020 after approval by Al Azhar Faculty of Medicine Ethical Review Committee. The search included 30 patients presented to the outpatient clinics with constipation or Fecal incontinence whom fulfilled the required Criteria.

\section{Criteria of the Study Candidates:}

Inclusion Criteria: Ages Eligible for Study: 8- 16 Years of age. Genders Eligible for Study: Both sex. Case of the study: All children presenting with chronic constipation or fecal incontinence. All children with persistent constipation or fecal incontinence following pull through operation for Hirsh sprung disease (HD).

Exclusion Criteria Children were excluded if they had constipation or incontinence with the following conditions: Patients under 8 years old. Children after pull through operation with stricture, missed segment or loss of sensory mucosa above the dentate line. Treated cases of anorectal malformations.

\section{Detailed Description:}

pre-operatively all patients will be subjected to the following full history taking, total clinical examination and investigations including complete blood picture, stool and urine analysis, serum creatinine, blood urea, fasting blood sugar, coagulation profile and liver function tests and imaging studies which including plain $\mathrm{x}$-ray abdomen erect and supine position, ultrasound abdomen and pelvis, gastrographin enema without preparation, defecography and dynamic MRI pelvic floor muscles if needed.

Pre-operative Preparation:

Informed Consent will be taken from the care giver, The child will be admitted in the ward. The preoperative preparation will include: 3-4 times daily enema for colonic preparation (using $20 \mathrm{ml} / \mathrm{kg}$ of warm saline).

All children was submitted for bowel management program for 3 months, if this management failed to solve the problem, the parents will be informed for the option of surgical intervention.This Program is consisted of 3 lines of managements (Dietary, Medication and Psychological). All three managements must work in parallel to get the optimum results.

Ethical consideration:

The protocol of the study was debated and accepted by Al-Azhar University's Ethical Research Committee for clinical study. The patient and family were clearly explained the procedures and the purpose of the research. Prior to participation in the study, a written, informed consent was obtained. Patients with perineal descent syndrome undergoes for laparoscopic techniques according to pre operative diagnosis, if Anterior rectocele a laparoscopic suture rectopexy to the sacral promontory will be done without mesh. If Posterior rectocele a laparoscopic mesh rectopexy( retro rectal Prolene mesh will be applied) and if Recto anal intussception and associated with motility disorder a laparoscopic assisted Trans- anal resection rectopexy will be done, If not associated with motility disorder a laparoscopic mesh rectopexy will be done.

Operative Technique:

Common steps in all 3 techniques: Under general endotracheal anaesthesia with muscle relaxant. The catheter had been inserted into Urethra. The patient was positioned $15^{\circ}-25^{\circ}$ supine in Trendelenburg. The assistant surgeon is at the left side of the patient, while the surgeon \& scrub nurse stand on the right side. Laparoscopy was initiated with an open Hasson's technique, using $5 \mathrm{~mm}$ cannula placed supra-umbilically. The peritoneal cavity was insufflated by carbon dioxide, to pressure between 8 and $14 \mathrm{~mm} \mathrm{Hg}$ according to the child's age and body formed. A 5-mm 30-degree telescope was used to visualize the pelvis and abdomen via the umbilical port including the rectum, sigmoid colon and their peritoneal coverings. Then two accessory cannulas (one for each lateral quadrant at or below the umbilicus level corresponding to the child's age and body built up) was put under direct vision for the insertion of coercive instruments by means of a stab incision. The Rt. working instrument was a hook electrocautery / a dissecting scissors or a needle holder while the Lt. working instrument was a grasper (laparoscopic Babcock forceps) (Fig. 1). The redundant rectosigmoid was delivered by atraumatic grasper from the pelvis (Fig. 2) and a traction suture was taken percutaneously via sigmoid colon seromuscular layer to put a traction on the rectosigmoid so the rectum was pulled relatively taut (Fig. 3). The peritoneum on the Rt. side of the rectum over the sacral promontory was incised with a scissor or an electrocautery hook, (Fig. 4) and exposing retrorectal space and presacral fascia with lateral rectal ligaments protection, we extend to the rectal posterior wall (with great care to secure the mesorectum, the ureter and the outer iliac vessels).The retrorectal dissection extended to the pelvic floor level 3-4 cm above line dentate (Fig. 5) Verified with a digital rectal inspection by a third assistant (this peritoneal incision and retrorectal dissection step was omitted in laparoscopic anterior wall suture rectopexy technique). then, either suture rectopexy (posterior or anterior) was done. In laparoscopic posterior wall suture rectopexy (Fig. 6) the rectal posterolateral wall was sutured and fixed by seromuscular sutures using a non-absorbable suture (Prolene 2/0) to the periosteum of the sacral 
promontory and presacral fascia, At the Rt. side of the rectum $2 \mathrm{~cm}$ apart. In laparoscopic anterior wall suture rectoexy (Fig. 7), the anterior rectal wall was sutured and fixed by seromuscular sutures to the supravesical fossa peritoneum, medial umbilical ligament and anterolateral pelvic wall without retrorectal dissection utilizing either Prolene $2 / 0$ or polydioxanone (PDS) 2/0. rectopexy of the mesh was achieved by inserting polypropylene (prolene) mesh (measuring about $7 \times 2 \mathrm{~cm}$.) retrorectally in the presacral space (Fig. 8) with fixation to the rectum \& the presacral fascia (Fig. 9) or without this fixation. trans anal assisted resection rectopexy in patients with recto anal intussception which associated with motility disorder. the peritoneal defect was closed at the end of each of the three techniques by continuous nonabsorbable (Prolene 2/0) suture (Fig. 10). The rectum extends in the pelvis directly with a slight degree of tension when the operation is complete. Deflating the abdomen and shutting the port sites (Fig. 11) with an absorbable suture (Polygalactin Vicryl-2/0).

Post operatively, patients were recommended to prevent strain \& constipation by maintaining a high fiber diet, adequate fluids, and laxatives. Follow-up of patients was arranged as follows: first outpatient visit 2 weeks post-operatively, then three monthly either at outpatient clinic or by telephone questionnaire. Three months later, the external anal sphincter and pelvic floor muscles of EMG were replicated.

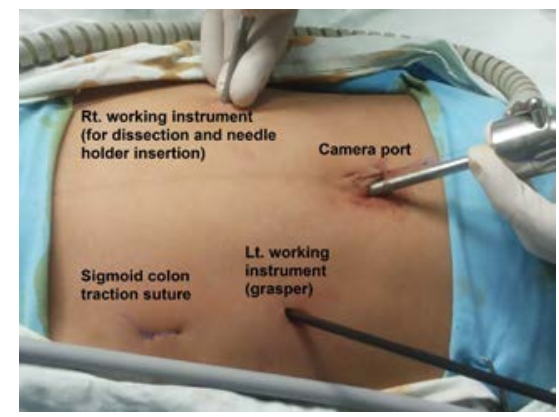

Fig. 1: Port sites.

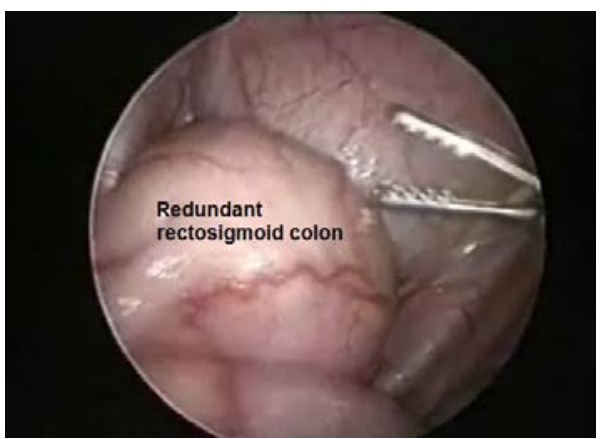

Fig. 2: Laparoscopic view of redundant rectosigmoid.

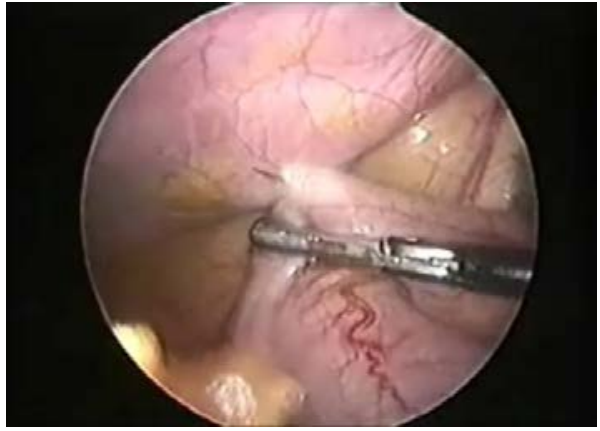

Fig. 3: Laparoscopic view of percutaneous rectosigmoid traction suture.

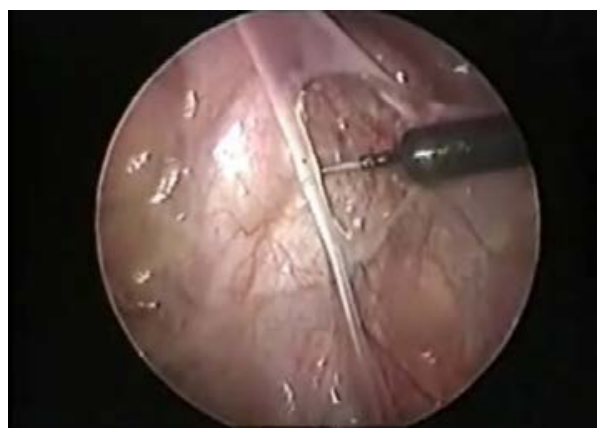

Fig. 4: Rt. pararectal peritoneal dissection using hook electrocautery

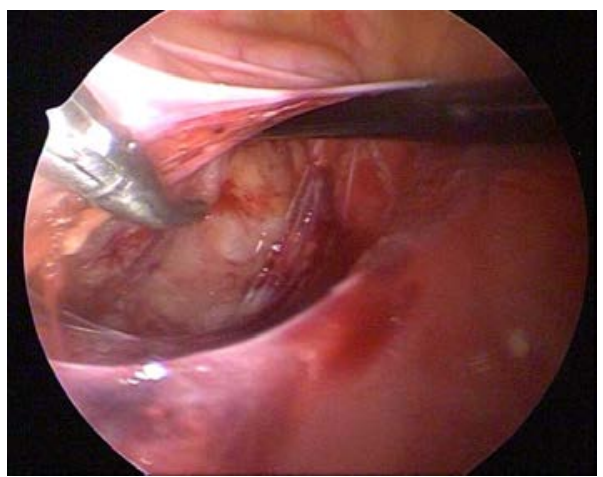

Fig. 5: Retrorectal dissection.

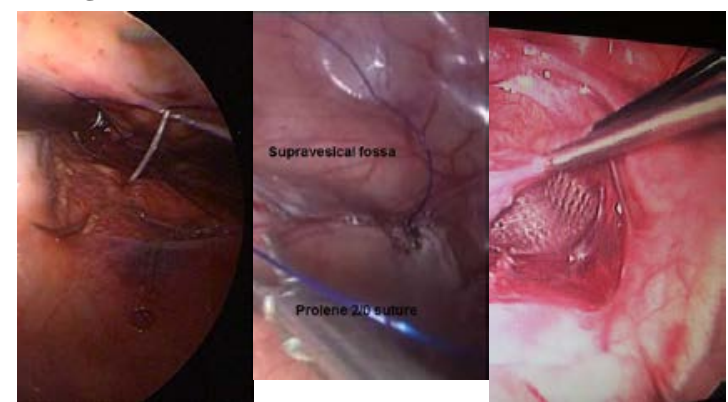

Fig.

6: Fig.

7: $\quad$ Fig. 8: Prolene Laparoscopic Laparoscopic mesh inserted posterior wall anterior wall retrorectally. suture suture rectopexy. rectopexy. 

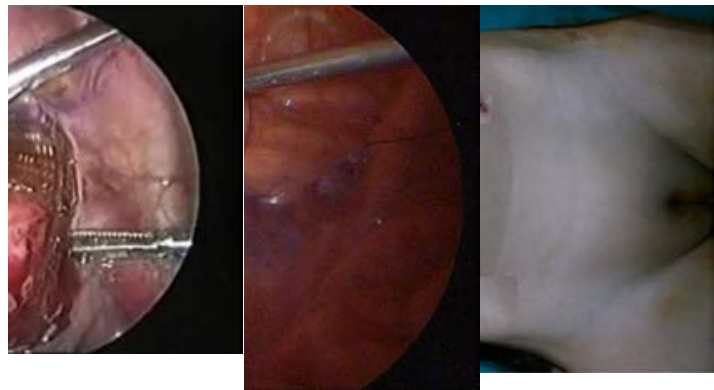

Fig. 9: $\quad$ Fig.

10: Fig. 11: Port Laparoscopic mesh Closure of the peritoneal rectopexy with defect. fixation.

\section{RESULTS}

\begin{tabular}{|c|c|c|c|c|c|}
\hline $\begin{array}{l}\text { Demograph } \\
\text { ic Data }\end{array}$ & $\begin{array}{l}\text { Ant. } \\
\text { Rectoc } \\
\text { ele }\end{array}$ & $\begin{array}{l}\text { Post. } \\
\text { Rectoc } \\
\text { ele }\end{array}$ & $\begin{array}{c}\text { Rectoanal } \\
\text { Intusscept } \\
\text { ion }\end{array}$ & $\begin{array}{c}\mathrm{t}- \\
\text { test }\end{array}$ & $\begin{array}{c}\text { p- } \\
\text { valu } \\
\text { e }\end{array}$ \\
\hline $\begin{array}{c}\text { Age (in } \\
\text { years) }\end{array}$ & & & & \multirow{3}{*}{$\begin{array}{c}0.30 \\
5\end{array}$} & \multirow{3}{*}{$\begin{array}{c}0.73 \\
9\end{array}$} \\
\hline $\begin{array}{l}\text { Mean } \pm \text { Stand } \\
\text { ard } \\
\text { deviation } \\
\end{array}$ & $\begin{array}{c}6.57 \pm \\
3.01\end{array}$ & $\begin{array}{c}5.66 \pm \\
3.37\end{array}$ & $5.66 \pm 3.37$ & & \\
\hline Range & 8-16 & 8-16 & 8-16 & & \\
\hline $\begin{array}{c}\text { Sex [No. } \\
(\%)]\end{array}$ & & & & \multirow{3}{*}{$\begin{array}{c}0.69 \\
4\end{array}$} & \multirow{3}{*}{$\begin{array}{c}0.70 \\
7\end{array}$} \\
\hline Female & $\begin{array}{c}5 \\
(33.3 \%) \\
\end{array}$ & $5(50 \%)$ & $2(40 \%)$ & & \\
\hline Male & $\begin{array}{c}10 \\
(66.6 \%) \\
\end{array}$ & $5(50 \%)$ & $3(60 \%)$ & & \\
\hline $\begin{array}{l}\text { Duration of } \\
\text { symptoms } \\
\text { (in years) }\end{array}$ & & & & \multirow{3}{*}{$\begin{array}{c}1.10 \\
5\end{array}$} & \multirow{3}{*}{$\begin{array}{c}0.34 \\
6\end{array}$} \\
\hline $\begin{array}{c}\text { Mean } \pm \text { Stand } \\
\text { ard } \\
\text { deviation } \\
\end{array}$ & $\begin{array}{c}2.31 \pm \\
1.02\end{array}$ & $\begin{array}{c}3.09 \pm \\
1.78\end{array}$ & $3.09 \pm 1.78$ & & \\
\hline Range & $8-16$ & $8-16$ & $8-16$ & & \\
\hline
\end{tabular}

Table 1: Demographic data for perineal descent syndrome

\begin{tabular}{|r|r|c|c|}
\hline Defecography & Technique & No & $\%$ \\
\hline Ant.Rectocele & Lap.suture Rectopexy & 15 & 50 \\
\hline Post. Rectocele & Lap.Mesh Rectopexy & 10 & 33.3 \\
\hline & $\begin{array}{r}\text { Lap.Assisted Resection } \\
\text { Rectopexy(with motility } \\
\text { disorder) }\end{array}$ & \multirow{2}{*}{5} & \multirow{2}{*}{16.7} \\
$\begin{array}{r}\text { Lap.Mesh } \\
\text { Rectoanal }\end{array}$ & & \\
\cline { 2 - 3 } intussception & $\begin{array}{r}\text { Rectopexy(without } \\
\text { motility disorder) }\end{array}$ & & \\
\cline { 2 - 4 } & &
\end{tabular}

Table 2: Distribution of PDS according to defecography results \& their techniques.

\begin{tabular}{|r|c|c|c|c|c|c|}
\hline $\begin{array}{r}\text { preoperative } \\
\text { bowel habit }\end{array}$ & \multicolumn{2}{|c|}{ constipation } & \multicolumn{2}{|c|}{$\begin{array}{c}\text { Fecal } \\
\text { incontinence }\end{array}$} & \multirow{2}{*}{ x2 } & $\begin{array}{c}\text { p- } \\
\text { value }\end{array}$ \\
\cline { 1 - 5 } Ant.Rectocele & 10 & $50.0 \%$ & 5 & $50.0 \%$ & & \\
\cline { 2 - 4 } $\begin{array}{r}\text { Post. } \\
\text { Rectocele }\end{array}$ & 5 & $25.0 \%$ & 5 & $50.0 \%$ & \multirow{2}{*}{3.750} & $\mathbf{0 . 1 5 3}$ \\
\cline { 2 - 3 } $\begin{array}{r}\text { Recto anal } \\
\text { intussception }\end{array}$ & 5 & $25.0 \%$ & 0 & $0.0 \%$ & & \\
\hline
\end{tabular}

Table 3: Perineal descent syndrome according to preoperative bowel habit.

\begin{tabular}{|c|c|c|c|c|c|c|c|c|}
\hline \multirow{2}{*}{$\begin{array}{c}\text { Paramete } \\
\mathbf{r}\end{array}$} & \multicolumn{2}{|c|}{$\begin{array}{c}\text { Suture } \\
\text { Rectopex } \\
\text { y }\end{array}$} & \multicolumn{2}{|c|}{$\begin{array}{c}\text { Mesh } \\
\text { Rectopex } \\
\mathbf{y}\end{array}$} & \multicolumn{2}{|c|}{$\begin{array}{c}\text { Resectio } \\
\text { n } \\
\text { Rectopex } \\
\text { y }\end{array}$} & \multicolumn{2}{|c|}{$\begin{array}{c}\text { Chi-square } \\
\text { test }\end{array}$} \\
\hline & $\begin{array}{l}\text { N } \\
\text { o. }\end{array}$ & $\%$ & $\begin{array}{l}\text { N } \\
\text { o. }\end{array}$ & $\%$ & $\begin{array}{l}\text { N } \\
\text { o. }\end{array}$ & $\%$ & $\mathrm{x} 2$ & $\begin{array}{c}\text { p- } \\
\text { valu } \\
\text { e }\end{array}$ \\
\hline \multicolumn{9}{|l|}{$\begin{array}{r}\text { Recurren } \\
\text { ce } \\
\end{array}$} \\
\hline $\begin{array}{l}\text { No } \\
\text { Yes }\end{array}$ & $\begin{array}{c}13 \\
2\end{array}$ & $\begin{array}{c}86 . \\
6 \\
13 . \\
3\end{array}$ & $\begin{array}{c}10 \\
0\end{array}$ & $\begin{array}{c}10 \\
0 \\
0\end{array}$ & $\begin{array}{l}5 \\
0\end{array}$ & $\begin{array}{c}10 \\
0 \\
0\end{array}$ & $\begin{array}{c}1.66 \\
7\end{array}$ & $\begin{array}{c}0.19 \\
7\end{array}$ \\
\hline \multicolumn{9}{|l|}{$\begin{array}{r}\text { Redo } \\
\text { operation } \\
\end{array}$} \\
\hline $\begin{array}{l}\text { No } \\
\text { Yes }\end{array}$ & $\begin{array}{c}13 \\
2\end{array}$ & $\begin{array}{c}86 . \\
6 \\
13 . \\
3\end{array}$ & $\begin{array}{c}10 \\
0\end{array}$ & $\begin{array}{c}10 \\
0 \\
0\end{array}$ & $\begin{array}{l}5 \\
0\end{array}$ & $\begin{array}{c}10 \\
0 \\
0\end{array}$ & $\begin{array}{c}1.66 \\
7\end{array}$ & $\begin{array}{c}0.19 \\
7\end{array}$ \\
\hline \multicolumn{9}{|l|}{ Post-op } \\
\hline $\begin{array}{r}\text { constipati } \\
\text { on } \\
\text { No } \\
\text { Yes }\end{array}$ & $\begin{array}{c}12 \\
3\end{array}$ & $\begin{array}{l}80 \\
20\end{array}$ & $\begin{array}{l}8 \\
2\end{array}$ & $\begin{array}{l}80 \\
20\end{array}$ & $\begin{array}{l}4 \\
1\end{array}$ & $\begin{array}{l}80 \\
20\end{array}$ & $\begin{array}{c}0.12 \\
0\end{array}$ & $\begin{array}{c}0.72 \\
9\end{array}$ \\
\hline
\end{tabular}

Table 4: Lap. management for PDS according to recurrence, redo operation and post-op constipation.

\section{DISCUSSION}

Perineal descent syndrome (PDS) is a phenomenon generally found in the pediatric community, most frequently observed between the ages of 8 and 16, where pelvic floor weakness is usually the cause unlike prolapse in adults, (e.g., after childbirth injury), children's etiology is generally idiopathic, particularly when setting up toilet training when parents are promoting extended commode time. . $^{3,4}$

Perineal descent syndrome (PDS) and Rectal prolapse is typically a self-limited problem in children without underlying conditions so its evaluation and treatment are initially conservative $6,7,8,9$

Constipation occurred in our sample in 20 cases (66.6\%); in comparison to 9 of 19 cases (47\%). ${ }^{7}$

Fecal incontinence was present in 10 cases (33.3\%), a low ratio compared to 5 of 8 cases $(62.5 \%){ }^{6}$ and compares with 8 of 19 cases (42\%). ${ }^{7}$ and also with 6 of 11 cases $(54.5 \%) .{ }^{10}$

Preoperative constipation occurred in 20 cases (66.6 $\%)$ of our study patients, almost half as reported (32 $\%, 6$ of 19 cases) ${ }^{7}$ compared with the $25 \%$ ratio (2 of 8 cases). ${ }^{6}$ and the $27 \%$ ratio ( 3 of 11 cases). ${ }^{10}$ This ratio also fall in the range other authors mentioned (3-53\%).

The basic objectives of surgical management of perineal descent syndrome and full rectal prolapse thickness is used to restore anatomy and physiology by controlling the external prolapse of the rectum; boost continence, boost bowel function (prevent constipation or evacuation impairment), and minimize the rate of recurrence with lower morbidity and death. ${ }^{9,11,12}$

The growing body of literature reinforces the idea that laparoscopic surgical procedures can offer the benefits of low recurrence rates safely, improved clinical outcome, fewer postoperative pain, shorter 
hospital stay, and early bowel function return in patients with perineal descent syndrome. ${ }^{2,12}$

Both laparoscopic rectopexy resection and laparoscopic rectopexy suture were defined with no resection; each having its own merits. ${ }^{13,14}$ A colonic resection however needs an abdominal incision and colonic anastomosis to recover the sample, which makes it time consuming and technically demanding. ${ }^{14}$

Laparoscopic complete posterior rectal mobilization and fastening to the sacrum alone has a high success rate, lower morbidity and mortality and lower sepsis and recurrence risk. ${ }^{2,9}$

In all cases of the study (except laparoscopic anterior suture rectopexy cases) unilateral right-side pararectal dissect was performed and none of them were bilaterally dissected to prevent exposure of both external iliac vessels and ureters to the possibility of injury during the operation. This is contrary with bilateral pararectal dissection. ${ }^{15}$ and circumferential (complete perirectal) dissection. ${ }^{8}$

In most cases of our study Polypropylene (Prolene) suture was used \& Polydioxanone (PDS) was used in 2 cases of laparoscopic anterior suture rectopexy. This is in contrast to the silk suture used for laparoscopic suture rectopexy. ${ }^{6,15,16}$

Laparoscopic with mesh fastening raises the length of the operation and the technological expertise necessary to perform the operation compared to laparoscopic suture rectopexy. ${ }^{17}$ in our study (The mean operating time for laparoscopic suture rectopexy was 45.7 minutes versus 62.05 minutes for laparoscopic mesh rectopexy).

Conversion rate was zero in our study. this compares with a conversion rate of $16 \%{ }^{18}$ while others reported zero percent conversion rates. ${ }^{15,19}$

Our research did not present any significant intraoperative or post-operational complications (e.g. port site inflammation, port-site hematoma, or bowel obstruction, or hernia, or fecal impaction, or pelvic collection)

Due to the extra time taken to change the mesh size, insert it and then change its position, the longer operating period in laparoscopic mesh rectopexy is understandable. In all cases of our research, rectal stalks (Lateral Rectal Ligaments) were conserved.

Oral intake in our study within 24.3 hours (range, 2030) after suture rectopexy \& 27.3 hours (range, 2235) after mesh rectopexy has been resumed \& 144 hours (range, 120-168) after resection rectopexy. No previous studies had mentioned or concerned with this issue.

The incidence of recurrence is one of the significant criteria for gauging the success of perineal descent syndrome surgery. Recurrence after suture rectopexy ranged from $0-3 \%{ }^{20}$

In our study ( $\mathrm{n}=30), 2$ recurrent cases $(13.3 \%)$ were found after laparoscopic suture rectopexy. Recurrence rates with mesh rectopexy or resection rectopexy was zero \% and the laparoscopic techniques have not substantially modified the rate of recurrence, which continues to be zero \% in a follow up period. This is comparable to a zero \% recurrence rate. ${ }^{2,6,16}$ This is also comparable to the partial recurrence rate of $11 \%$ and $5.5 \%$ of the full-thickness recurrence. ${ }^{7}$ and $5 \%$ of partial recurrence. ${ }^{15}$ an unusually very high, frustrating fault levels with rectopexy laparoscopic suture $[100 \%$ of their cases $(n=5)] .^{10}$

Six cases (20\%) were post-operatively constipated in our study [3 cases (20\%) followed laparoscopic suture rectopexy and 2 cases (20\%) followed laparoscopic mesh rectopexy and 1 case (20\%) followed laparoscopic resection rectopexy]. This is in comparison with postoperative constipation following posterior sagittal rectopexy (PSRP) in 1 case and 2 of 8 cases (25\%) after LSRP. ${ }^{6}$ They said constipation was the only postoperative concern and is frequently exacerbated. 1 case of post-operative constipation formed by $40(2.5 \%){ }^{2}$ and 1 case of post-operative constipation $52(1.9 \%)^{19}$ Similarly, recorded post-operative constipation in 1 case of 19 (5.3\%). ${ }^{15}$ On the opposite, zero \% post-operative constipation. $^{8}$

It was hypothesised that lack of rectum compliance after rectopexy or a redundant sigmoid loop could be related to constipation., ${ }^{21}$

Rectal prolapse is equally well controlled by laparoscopic rectopexy, whether resected with or without sigmoid. ${ }^{22}$ The rectal lateral ligaments were not partitioned according to LSRP technique. If the ligaments can be maintained, patients may tend to have less constipation and incontinence. ${ }^{23}$

Based on this improvement in constipation in our research, the surgical technique employed in which the lateral ligaments for rectal mobilization have not been split may be attributed. Sepsis and a higher incidence of constipation are associated with the use of prothetic mesh in posterior mesh rectopexy to induce fibrosis and promote fixation. ${ }^{24}$

Suture rectopexy was shown to be similarly effective in preventing recurrence as mesh rectopexy, but prevents post-operative sepsis problems and increased constipation. ${ }^{9,25}$

\section{CONCLUSION}

The anterior rectal wall has a great dynamic role in defecation thanks to its viscoelastic properties. It mimics a smooth massaging hand that presses upon the posterior rectal wall against the sacrum to help expel the rectal contents during the defecation act. Any rectopexy technique should never interfere or impede this vital mechanism of action. Finally chronic conistipation and fecal incontinence are considered as a hidden cause for perineal descent syndrome.

\section{REFERENCES}

1. Bharucha E, Blandon A, Roberta E, et al. Anatomy and Physiology of Continence In Carlo Ratto and Giovanni B. Doglietto eds.In Fecal Incontinence, diagnosis and treatment Springer., 2005 ;1:3-16. 
2. Ismail M, Gabr K, Shalaby R. Laparoscopic management of persistent complete rectal prolapse in children. J Pediatr Surg., 2010; 45(3):533-9.

3. Siafakas C, Vottler TP, Andersen JM. Rectal prolapse in pediatrics. Clin Pediatr (Phila)., 1999; 38:63-72.

4. Tashiro $\mathrm{J}$ and Burnweit CA. Rectal prolapse unreduced for 4 months in a premature neonate. $J$ Ped Surg Case Reports 2., 2014; 28-9.

5. Brown AJ, Anderson JH, McKee RF, et al. Strategy for selection of type of operation for rectal prolapse based on clinical criteria. Dis Colon Rectum, 2004; 47:103-7.

6. Koivusalo A, Pakarinen M, Rintala R. Laparoscopic suture rectopexy in the treatment of persisting rectal prolapse in children A preliminary report. Springer. Surg Endosc., 2006; 20(6):960-3.

7. Potter DD, Bruny JL, Allshouse MJ, et al. Laparoscopic suture rectopexy for full-thickness anorectal prolapse in children: an effective outpatient procedure. J Pediatr Surg., 2010; 45(10):2103-7.

8. Gomes-Ferreira C, Schneider A, Philippe P, et al. Laparoscopic modified Orr-Loygue mesh rectopexy for rectal prolapse in children. J Pediatr Surg., 2015; 50(2):353-5.

9. Yehya A, Gamaan I, Abdelrazek $M$, et al. Laparoscopic Suture versus Mesh Rectopexy for TheTreatment of Persistent Complete Rectal Prolapse in Children: A Comparative Randomized Study. Minimally Invasive Surgery, 2020; 1-8.

10. Randall J, Gallagher H, Jaffray B. Laparoscopic rectopexy for external prolapse in children. $J$ Pediatr Surg., 2014; 49(9):1413-5.

11. Sander S, Vural O, Unal M. Management of rectal prolapse in children. Ekehorn's rectosacropexy. Pediatr Surg Int., 1999; 15:111.

12. Senagore AJ. Management of rectal prolapse: the role of laparoscopic approaches. Semin Laparosc Surg., 2003; 10(4):197-202.

13. Hartley JE, Farouk R, Monson JR. Laparoscopic suture rectopexy for full thickness rectal prolapse. Minim Invasive Ther Allied Technol., 1996; 5: 540-2.
14. Stevenson AR, Stitz RW, Lumley JW. Laparoscopic assisted resection rectopexy for rectal prolapse: early and medium follow-up. Dis Colon Rectum., 1998; 41: 46-4.

15. Puri B. Rectal prolapse in children: Laparoscopic suture rectopexy is a suitable alternative. $J$ Indian Assoc Pediatr Surg., 2010; 15(5):47-9.

16. Laituri CA, Garey CL, Fraser JD, et al. 15-Year experience in the treatment of rectal prolapse in children. J Pediatr Surg., 2010; 45(8):1607-9.

17. Thandinkosi E, Madiba M, Mirza KB. Surgical management of rectal prolapse. Arch Surg., 2005; 140: 63-73.

18. Heah SM, Hartley JE, Hurley J, et al. Laparoscopic rectopexy without resection is effective treatment for full thickness rectal prolapse. Dis Colon Rectum, 2000; 43: 638-43.

19. Shalaby $\mathrm{R}$, Ismail $\mathrm{M}$, Abdelaziz $\mathrm{M}$, et al. Laparoscopic mesh rectopexy for complete rectal prolapse in children: a new simplified technique. Pediatr Surg Int., 2010; 26(8):807-13.

20. Graf W, Karlbom U, Pahlman L. Functional results after abdominal suture rectopexy for rectal prolapse or intussusception. Eur J Surg., 1996; 162: 905-11.

21. Abcarian $\mathrm{H}$ and Pemberton J. Prolapse and procidentia. In: Schakelford RT, Zuidema GD (eds) Surgery of the alimentary tract, $5^{\text {th }}$ ed. Saunders, Philadelphia, 2002; 410-20.

22. Kairaluoma MV, Viljakka MT, Kellokumpu IH. Open vs. laparoscopic surgery for rectal prolapse: a case-controlled study assessing short-term outcome. Dis Colon Rectum, 2003; 46:353-560.

23. Madiba TE, Baig MK, Wexner SD. Surgical management of rectal prolapse. Arch Surg., 2005; 140(1):63-73.

24. Sayfan J, Pinho M, Alexanders WJ, et al. Sutured posterior abdominal rectopexy with sigmoidectomy compared with Marlex mesh rectopexy. Br J Surg., 1990; 77: 143-5.

25. Kessler H, Jerby BL, Milsom JW. Successful treatment of rectal prolapse by laparoscopic suture rectopexy. Surg Endosco., 1999; 13: 858-861. 